\title{
Ochrona podmiotowości prawnej osób niepełnosprawnych intelektualnie w stopniu umiarkowanym w prawie polskim*
}

\section{Protection of the legal personality of people with moderate intellectual disability in Polish law}

\author{
Iwona Radlińska
}

Pomorski Uniwersytet Medyczny w Szczecinie, Katedra i Zakład Zdrowia Publicznego, ul Żołnierska 48, 71-210 Szczecin

$\triangle$ iwona.radlinska@pum.edu.pl

\begin{abstract}
Introduction: The aim of the study was to determine if Polish law provides protection for the legal personality of people with moderate intellectual disabilities in accordance with the guidelines of international law, especially the model of supported decision-making.

Materials and methods: The research material primarily involved sources of Polish constitutional and civil law, which were compared with sources of international law. The selected method relied on the analysis of legal acts.

Results: "Legal capacity", mentioned in Article 12 of the United Nations Convention on the Rights of Persons with Disabilities (2006), means the capability to act on an equal basis with others. In Polish law this concept is narrower - it means being subject to the law. However, the ability to act in one's own name requires having the "ability to perform legal actions". In the acts
\end{abstract}

on personal civil law (Civil Code, Family and Guardianship Code) a model of "substitute decision-making" is enabled, where an appropriate guardian or curator acts in the name of a person with intellectual disabilities who has no or limited "ability to perform legal actions" (incapacitated fully or partially, respectively). Conclusions: Legal incapacitation and guardianship expressing the „substitute decision-making model” are recommended for removal from personal civil law and introducing personal forms of "supported decision-making" as a legal assistant support. The scope of assistance provided by the assistant should be individually identified by the term of actual inability to make the own decisions by a person with intellectual disabilities (in respect of which an assistant has the right to operate) in the court order. Keywords: legal capacity; law; supported decision-making; assistant to a disabled person.

\begin{abstract}
ABSTRAKT
Wstęp: Ochrona podmiotowości prawnej osób z niepełnosprawnością intelektualną obejmuje, zgodnie z prawem międzynarodowym, poszanowanie autonomii jednostki z zachowaniem prawa do podejmowania samodzielnych wyborów. Prawo to nakazuje wprowadzenie modelu „wspomaganego podejmowania decyzji" w miejsce modelu „zastępczego", a przez to rezygnację z instytucji ubezwłasnowolnienia osoby oraz z opiekuna.

Celem pracy było określenie, czy prawo polskie zapewnia ochronę podmiotowości prawnej osób z niepełnosprawnością intelektualną w stopniu umiarkowanym zgodną z wytycznymi prawa międzynarodowego.

Materiały i metody: Materiał badawczy obejmował przede wszystkim źródła prawa polskiego - konstytucyjnego i cywilnego, które skonfrontowano ze źródłami prawa międzynarodowego. Wybrana metoda obejmowała analizę aktów prawnych. Wyniki: Zdolność prawna z art. 12 Konwencji ONZ o prawach osób niepełnosprawnych z 2006 r. oznacza możliwość działania na równi z innymi osobami. W polskim prawie to pojęcie jest węższe - oznacza bycie podmiotem prawa. Natomiast
\end{abstract}

możliwość działania w swoim imieniu wymaga posiadania zdolności do czynności prawnych. W aktach rangi ustawy (kodeks cywilny, kodeks rodzinny i opiekuńczy) umożliwiony jest przede wszystkim model zastępczego podejmowania decyzji, w którym w imieniu osoby z niepełnosprawnością intelektualną, pozbawionej lub ograniczonej w zdolności do czynności prawnych (ubezwłasnowolniona odpowiednio całkowicie lub częściowo), występuje odpowiednio opiekun lub kurator.

Wnioski: Zaleca się usunięcie z osobowego prawa cywilnego instytucji ubezwłasnowolnienia oraz opieki, wyrażających „zastępczy model podejmowania decyzji”, a w ich miejsce wprowadzenie osobowych form wspieranego podejmowania decyzji w postaci pomocy asystenta prawnego. Zakres pomocy świadczonej przez asystenta powinien być indywidualnie oznaczony w postaci określenia faktycznej niezdolności do czynności osoby z niepełnosprawnością intelektualną (w zakresie której ma prawo działać asystent) w postanowieniu sądu.

Słowa kluczowe: zdolność prawna; prawo; wspomagane podejmowanie decyzji; asystent osoby niepełnosprawnej.

* Praca stanowi część rozprawy doktorskiej przyjętej przez Radę Wydziału Nauk o Zdrowiu Pomorskiego Uniwersytetu Medycznego w Szczecinie. Promotor: prof. dr hab. n. zdr. Beata Karakiewicz. Oryginał obejmuje: 288 stron, 25 tabel, 4 ryciny oraz piśmiennictwo podzielone na 95 pozycji źródeł prawa, 9 pozycji orzecznictwa oraz 187 pozycji literatury przedmiotu. 


\section{WSTEP}

Ochrona praw osób niepełnosprawnych jest ściśle związana z ochroną praw człowieka. Dopiero XX w., a szczególnie okres rozpoczynający się po II wojnie światowej, okazał się przełomowy w tworzeniu aktów prawa międzynarodowego o zasięgu światowym [1,2,3] oraz europejskim [4], bezwzględnie chroniących człowieka, ze względu na jego przyrodzoną i niezbywalną godność. Oznaczało to ochronę każdej istoty ludzkiej, bez względu na rasę, płeć, narodowość, stan majątkowy czy inne różnice (w tym niepełnosprawność). Dokumenty te okazały się niewystarczające do ochrony praw osób niepełnosprawnych, dlatego zaczęto tworzyć akty adresowane wyłącznie do nich. Prawa osób niepełnosprawnych intelektualnie (NI) zostały po raz pierwszy ujęte w Deklaracji praw osób z upośledzeniem umysłowym Organizacji Narodów Zjednoczonych (ONZ) z 20 grudnia 1971 r. [5], w której podkreślono, że osoby te mają prawo do takiej samej ochrony prawnej jak inni ludzie. W preambule deklaracji z 1971 r. podkreśla się konieczność udzielania pomocy osobom z „upośledzeniem umysłowym” w rozwijaniu ich zdolności i możliwości w różnych dziedzinach działania oraz potrzebę tworzenia warunków umożliwiających integrację w normalnym życiu możliwie w największym stopniu. Realizacja powyższych praw do: „autonomii” oraz „integracji” ma się odbywać przy zapewnieniu odpowiedniej pomocy prawnej gwarantowanej przez państwo - szczególnie wsparcia osobowego.

Później wydane deklaracje ONZ, m.in. Deklaracja praw osób niepełnosprawnych z dnia 9 grudnia 1975 r. [6] oraz Standardowe zasady wyrównywania szans osób niepełnosprawnych z 20 grudnia 1993 r. [7], stanowiące zwyczajowe prawo międzynarodowe w zakresie standardów ochrony praw osób niepełnosprawnych, podkreślały potrzebę udzielania pomocy w zapewnieniu niezależności osoby bez względu na rodzaj i stopień niepełnosprawności oraz zapewnienia profesjonalnej pomocy służb wspierających. Wdrożenie deklaracji państw i zwyczajowych standardów ochrony, będących prawem rangi soft law (bez skutków prawnych dla państw w razie jego nieprzestrzegania), nastąpiło w pełni w Konwencji o prawach osób niepełnosprawnych z 13 grudnia 2006 r. - KPON [8] (prawo rangi hard law - wdrażanie aktu nadzoruje Komitet Praw Osób z Niepełnosprawnościami), ratyfikowana przez Unię Europejską (UE) w 2010 r., a przez Polskę w 2012 r. (bez fakultatywnego protokołu dotyczącej skarg obywateli - obywatele Polscy nie mogą składać skarg do Komitetu).

Dodatkowo w ramach prawa obowiązującego w Europie wydana została m.in. Rekomendacja Rady Europy z 23 lutego 1999 r. w sprawie zasad dotyczących prawnej ochrony niekompetentnych osób dorosłych [9]. Osoby „niekompetentne” to przede wszystkim osoby z NI, którym należy zapewnić maksymalną samodzielność w podejmowaniu decyzji. Zakres „niekompetencji” winien być ustalany indywidualnie i w tym zakresie należy zapewnić pomoc prawną, a nie zastępstwo $\mathrm{w}$ podejmowaniu decyzji. W zasadzie $\mathrm{w}$ dokumencie tym zakazano całościowego ubezwłasnowolnienia osoby. Późniejsze rekomendacje Rady Europy [10,11] podkreślają konieczność zapewnienia osobom z NI pełnej „zdolności do czynności prawnych", przy zapewnieniu odpowiedniego wsparcia państwa.

Powyższe regulacje prawa międzynarodowego i europejskiego wyodrębniły i rozwinęły model „wspieranego (wspomaganego - używane zamiennie) podejmowania decyzji” (supported decision-making), mający zastąpić model „zastępczego podejmowania decyzji” (subtitute decision-making). W modelu wspierającym promuje się wprowadzenie niezbędnej do podejmowania decyzji pomocy w postaci przede wszystkim pomocy osobowej (pomoc asystenta), która ma wyeliminować zastępstwo prawne, na mocy którego opiekun podejmuje decyzje w imieniu podopiecznego. Asystent winien działać w indywidualnie ustalonym, niezbędnym zakresie niekompetencji osoby, nie podejmując za nią decyzji, lecz świadcząc pomoc w jej podjęciu lub realizacji. Asystent działa zatem razem z osobą - asystuje jej w wyznaczonym zakresie. W celu określenia zakresu niekompetencji osoby do podejmowania decyzji (a tym samym zakresu niezbędnego wsparcia prawnego) w procesie decyzyjnym wyodrębniono kilku etapów:

- zrozumienie znaczenia informacji związanych z podejmowaną decyzją, szczególnie w zakresie skutków podjętych decyzji/działań,

- podjęcie swobodnej decyzji,

- komunikacja decyzji w zrozumiały dla innych sposób.

W myśl modelu „wspomagania decyzji” osobie należy zapewnić, w razie konieczności, wsparcie osobowe bądź techniczne na każdym z powyższych etapów, co doprowadzi do podjęcia konkretnej decyzji przez tę osobę, bez konieczności decydowania za nią i w jej imieniu [12]. Model „wspomagania” jest szczególnie istotny wobec osób z NI w stopniu umiarkowanym, ponieważ wymagają wsparcia w niektórych dziedzinach życia (np. poszukiwanie pracy czy jej wykonywanie).

Czy prawo polskie zapewnia odpowiednią ochronę podmiotowości prawnej osób z NI w stopniu umiarkowanym, zgodnie z regulacjami międzynarodowymi, szczególnie modelem „wspomaganego podejmowania decyzji”? Celem pracy było znalezienie odpowiedzi na to pytanie.

\section{MATERIAŁY I METODY}

W kontekście podmiotowości prawnej osób z NI, w tym w stopniu umiarkowanym, w pracy omówiono wybrane normy prawa konstytucyjnego zawartego w Konstytucji RP z dnia 2 kwietnia 1997 r. [13] oraz prawa cywilnego materialnego ujętego w przepisach: ustawy z dnia 23 kwietnia 1964 r. - Kodeks cywilny (KC) [14], ustawy z dnia 25 lutego 1964 r. - Kodeks rodzinny i opiekuńczy (KRO) [15], a następnie prawa cywilnego procesowego zawartego głównie w ustawie z dnia 17 listopada 1964 r. - Kodeks postępowania cywilnego (KPC) [16]. Akty te regulują dwa elementy podmiotowości prawnej: „zdolność prawną” i „zdolność do czynności prawnych”. Prawo materialne cywilne reguluje stosunki majątkowe i niemajątkowe między równymi wobec siebie podmiotami prawa, natomiast procesowe dotyczy działania organów rozpoznających sprawy cywilne z udziałem tych podmiotów. Postępowanie cywilne 
służy zatem zrealizowaniu norm prawa materialnego cywilnego. Przy czym normy prawa materialnego znajdują się przede wszystkim w KC, KRO, jakkolwiek mogą wystąpić w KPC (np. zdolność sądowa). Natomiast normy prawa procesowego występują czasem również w kodeksach regulujących prawo materialne [17]. W analizie tych aktów prawnych korzystano z tekstów dostępnych w internetowych bazach: dziennika urzędowego Unii Europejskiej - Eur-Lex (dzienniki ustaw UE) [18], polskiego Internetowego Systemu Aktów Prawnych zawierającego polskie publikatory (Dzienniki Ustaw) [19]. Do analizy aktów prawnych wykorzystano przede wszystkim dostępną literaturę prawniczą.

\section{WYNIKI}

\section{Postanowienia Konstytucji Rzeczypospolitej Polskiej}

W art. 32 Konstytucji RP wpisana jest zasada równości, oznaczająca, że wszyscy są wobec prawa równi, co oznacza „prawo do równego traktowania przez władze publiczne” oraz „zakaz dyskryminacji", nikt bowiem nie może być dyskryminowany w życiu politycznym, społecznym i gospodarczym z jakiejkolwiek przyczyny. W kontekście wspomnianych przepisów antydyskryminacyjnych oraz „zasady równości” wobec prawa należy zapewnić osobom niepełnosprawnym, w tym intelektualnie, realizację całego katalogu praw człowieka z rozdziału II Konstytucji RP [13] z uwzględnieniem przepisów uprzywilejowujących - m.in. z art. 67 (prawo do zabezpieczenia społecznego w przypadku niezdolności do pracy ze względu na chorobę lub inwalidztwo), art. 68 (szczególna ochrona zdrowia osób niepełnosprawnych) oraz art. 69 (pomoc dla osób niepełnosprawnych w zakresie egzystencji, przysposobieniu pracy i komunikacji) - związanych z realizacją „zasady wyrównywania szans”.

Ponadto, jak podkreśla Zima-Parjaszewska [20], należy zachować ostrożność w stosowaniu art. 31 ust. 3 Konstytucji w zakresie wprowadzenia ograniczeń konstytucyjnych wolności i praw. Może to nastąpić w drodze ustawy i tylko wówczas, gdy jest to konieczne dla bezpieczeństwa lub porządku publicznego bądź dla ochrony środowiska, zdrowia i moralności publicznej oraz wolności i praw innych osób. Tym ograniczeniem ustanowionym w związku z art. 31 ust. 1 jest wprowadzenie w polskim prawie (KC, KPC, KRO) instytucji ubezwłasnowolnienia jako formy odebrania „zdolności do czynności prawnych”. Autorka podnosi, że ubezwłasnowolnienie nie spełnia przesłanek dozwolonej ingerencji w konstytucyjne wolności i prawa, a ponadto łamie postanowienia KPON, gdzie zawarta jest „zasada autonomii” jednostki oraz „zasada równości wobec prawa" z obowiązkiem zapewnieniem wsparcia państwa (nie opieki) przy realizacji „zdolności prawnej” z art. 12. Ponadto inne kraje UE, które ratyfikowały KPON, stosują obecnie różne środki wsparcia zastępujące ubezwłasnowolnienie [21].

\section{Przepisy Kodeksu cywilnego}

Najważniejszym aspektem prawa cywilnego materialnego, z punktu widzenia ochrony praw osób z NI, w tym w stopniu umiarkowanym, jest uznanie ich podmiotowości prawnej, a przede wszystkim zapewnienie możliwości podejmowania decyzji. Zgodnie z KC każdy człowiek od chwili urodzenia posiada „zdolność prawną” (art. $8 \mathrm{KC}$ ), jednak do ukończenia 13. r.ż. nie ma „zdolności do czynności prawnych” (art.12. KC), zaś osoba między 13. a 18. r.ż. oraz osoba ubezwłasnowolniona częściowo mają „ograniczoną zdolność do czynności prawnych” (art. $15 \mathrm{KC}$ ). Cytowane artykuły zawierają dwa elementy podmiotowości prawnej: „zdolność prawną” i „zdolność do czynności prawnych”. Chociaż „zdolność prawna” jest pojęciem normatywnym, nie została zdefiniowana w art. 8, ze względu na to, że rozumienie go jest utrwalone i niebudzące wątpliwości. W przypadku osób fizycznych jako istot ludzkich uznaje się, że „zdolność prawna” oznacza zdolność do bycia podmiotem praw i obowiązków cywilnoprawnych. „Zdolności prawnej” nie można się zrzec ani jej ograniczyć, bowiem przysługuje każdemu człowiekowi w takim samym zakresie. Powstanie „zdolności prawnej” łączy się ściśle z powstaniem człowieka (osoby fizycznej), ponieważ następuje z mocy prawa w momencie żywego urodzenia, a jej wygaśnięcie zachodzi w momencie śmierci. Żeby istniała osoba fizyczna, muszą być spełnione dwa warunki łącznie: istnienie ciała ludzkiego oraz trwanie życia ludzkiego. Odmienne cechy ma „zdolność do czynności prawnych" [22], drugi komponent podmiotowości prawnej osoby fizycznej, oznacza bowiem możność nabywania praw i obowiązków z zakresu prawa cywilnego własnym działaniem oraz we własnym imieniu [22]. Wobec tego z mocy prawa nie przysługuje od chwili urodzenia, a między 13. a 18. r.ż. jest ograniczona (ograniczona zdolność do czynności prawnych). Ponadto może być ograniczona wobec osób pełnoletnich. Od momentu, gdy osoba ukończy 13 lat, może być ubezwłasnowolniona całkowicie z powodu m.in. niedorozwoju umysłowego albo innego rodzaju zaburzeń psychicznych, przez co nie jest w stanie kierować swym postępowaniem (art. 13 § $1 \mathrm{KC}$ ). Zgodnie z art. $12 \mathrm{KC}$ ubezwłasnowolnienie całkowite powoduje, że nie posiada się „zdolności do czynności prawnych”, a więc jest to stan prawny jak dziecka od urodzenia do ukończenia 13. r.ż. Wobec tego bezprzedmiotowe jest ubezwłasnowolnienie dzieci poniżej 13. r.ż. [22].

„Pełną zdolność do czynności prawnych” nabywa się z chwilą uzyskania pełnoletności (art.11 KC), a pełnoletnim jest ten, kto ukończył 18 lat (art. 10 § 1 i 2 KC). Wcześniej, bo już w wieku 16 lat, pełnoletność może uzyskać kobieta przez zawarcie małżeństwa. Od momentu uzyskania pełnoletności osoba może być ubezwłasnowolniona częściowo (art. 16 § $1 \mathrm{KC}$ ) z powodów takich samych, jak w przypadku ubezwłasnowolnienia całkowitego, ,jeżeli stan tej osoby nie uzasadnia jednak ubezwłasnowolnienia całkowitego, lecz potrzebna jest pomoc do prowadzenia jej spraw". Dla osoby ubezwłasnowolnionej częściowo ustanawia się kuratelę (art. 16 § 2 KC). Ubezwłasnowolnić częściowo można zatem tylko osobę pełnoletnią, a kurator ma pomóc w prowadzeniu jej spraw [22].

Zakres czynności możliwych do podjęcia przez osobę „niezdolną do czynności prawnych” jest niewielki. Z reguły, jak czytamy w art. $14 \mathrm{KC}$ : „czynność prawna dokonana przez osobę, która nie ma zdolności do czynności prawnych, jest nieważna". Jednakże w dalszej części art. 14 KC podawane 
są warunki konwalidacji czynności dokonanej przez osobę niezdolną, tj.: umowa należy do umów powszechnie zawieranych w drobnych bieżących sprawach życia codziennego, nie pociąga za sobą rażącego pokrzywdzenia osoby niezdolnej oraz została wykonana. Umowy, które może zawrzeć niezdolny do czynności prawnych, to drobne zakupy (zabawka, książka, żywność), sprzedaż swoich rzeczy czy działalność wytwórcza (np. na kiermaszu). Ustawa nie podaje katalogu tych umów. W toku sprawy sąd bada, czy daną czynność można zaliczyć do tej kategorii umów, biorąc pod uwagę wiek i inne okoliczności. Wykonanie umowy oznacza wydanie przedmiotu osobie kupującej etc. [22].

Natomiast możliwości osoby „ograniczonej w zdolności do czynności" są, jak sama nazwa wskazuje, jedynie ograniczone i należą do grupy czynności, które wymagają zgody jej przedstawiciela ustawowego (którym jest opiekun prawny, np. rodzic albo kurator), albo do grupy czynności, które osoba może podejmować całkowicie samodzielnie. Z zastrzeżeniem przewidzianych w ustawie wyjątków, do ważności czynności prawnej zobowiązującej lub rozporządzającej, dokonywanych przez osobę z „ograniczoną zdolnością do czynności prawnych", potrzebna jest zgoda jej przedstawiciela ustawowego (art. 17 KC). Natomiast ważność umowy, zawartej przez osobę „ograniczoną w zdolności do czynności prawnych” bez wymaganej zgody przedstawiciela ustawowego, zależy od potwierdzenia przez niego umowy bądź potwierdzenia umowy po uzyskaniu pełnej zdolności do czynności prawnych przez tę osobę (art. 18 § 1 i 2 KC). Zgodnie z art. 18 § 3 KC strona, która zawarła umowę jedynie z osobą „ograniczoną w zdolności do czynności prawnych", może wyznaczyć przedstawicielowi ustawowemu odpowiedni termin w celu potwierdzenia umowy, a umowa staje się nieważna po bezskutecznym upływie wyznaczonego terminu. Zatem osoba ubezwłasnowolniona częściowo czy osoba między 13. a 18 r.ż. nie może działać bez zgody przedstawiciela ustawowego w sprawach wszelkich umów, gdzie zaciąga się zobowiązanie czy rozporządza swoim prawem (kupno-sprzedaż, wynajem, dzierżawa, odrzucenie spadku etc.) jednostronna czynność osoby w tym zakresie jest nieważna (art. 19 KC). Jednocześnie osoba może działać samodzielnie w zakresie czynności niebędących zobowiązaniem albo rozporządzeniem. Przykładowo może udzielić pełnomocnictwa w ramach swej zdolności do czynności prawnych czy przyjąć darowiznę [23]. Ponadto może samodzielnie zawierać umowy należące do umów powszechnie zawieranych w drobnych bieżących sprawach życia codziennego (art. $20 \mathrm{KC}$ ), rozporządzać swoim zarobkiem, chyba że sąd opiekuńczy z ważnych powodów inaczej postanowi (art. 21 KC), w pełni rozporządzać przedmiotami majątkowymi oddanymi do swobodnego użytku przez przedstawiciela ustawowego (rodzic, opiekun, kurator). W tym drugim zakresie mogą być to czynności rozporządzające, np. podarowanie prezentu urodzinowego innej osobie.

Warunki ważności dokonanej czynności określają też przepisy ogólne, jak np. art. 82 KC określający „wady oświadczenia woli”, który mówi o tym, że nieważne jest oświadczenie woli złożone przez osobę, która z jakichkolwiek powodów znajdowała się w stanie wyłączającym świadome albo swobodne powzięcie decyzji i wyrażenie woli. Dotyczy to w szczególności niedorozwoju umysłowego albo innego, chociażby nawet przemijającego zaburzenia czynności psychicznych. Jednak klauzula z art. 82 KC jest możliwa do unieważnienia umowy w toku sprawy sądowej, gdzie będzie trzeba udowodnić brak świadomości (np. przedstawienie orzeczenia o niepełnosprawności).

Podsumowując, pozbawienie albo ograniczenie „zdolności do czynności prawnych” osoby poprzez odpowiednio ubezwłasnowolnienie całkowite bądź częściowe ma na celu zabezpieczenie jej przed skutkami jej własnych decyzji, gdy nie jest w stanie kierować swoim postępowaniem lub rozpoznać znaczenia swoich czynów. Stan osób z NI w stopniu umiarkowanym, ze względu na potrzebę pomocy do prowadzenia niektórych ich spraw, może uzasadniać co najwyżej zastosowanie ubezwłasnowolnienia częściowego z art. 16 KC, które pozwoli im na pewne decyzje i nie wyłączy całkowicie z procesu decyzyjnego dotyczącego ich życia. Jednak docelowo, zgodnie z art. 12 KPON, należy dążyć do zniesienia nawet instytucji ubezwłasnowolnienia częściowego i rezygnować z „zastępczych form podejmowania decyzji” na rzecz „wspomaganych form podejmowania decyzji" poprzez zapewnienia wsparcia asystentów prawnych. Jeśli osoba nie jest ubezwłasnowolniona, decyzja o rozporządzeniu np. majątkiem może być badana pod względem ważności oświadczenia woli. Zgodnie z art. 82 KC brak świadomości, ze względu na „niedorozwój umysłowy”, spowoduje nieważność czynności.

\section{Przepisy Kodeksu rodzinnego i opiekuńczego}

Elementy regulujące podmiotowość prawną osób z NI zawierają regulacje KRO związane z możliwością zawarcia małżeństwa oraz pieczą zastępczą. Zgodnie z art. 12 § $1 \mathrm{KRO}$ nie może zawrzeć małżeństwa osoba dotknięta m.in. niedorozwojem umysłowym. Jeżeli jednak stan zdrowia lub umysłu takiej osoby nie zagraża małżeństwu ani zdrowiu przyszłego potomstwa i jeżeli osoba ta nie została ubezwłasnowolniona całkowicie, sąd może jej zezwolić na zawarcie małżeństwa. W szczególności niedorozwój umysłowy jednego z małżonków jest podstawą do unieważnienia małżeństwa na podstawie wniosku złożonego przez choćby jednego z małżonków (art. 12 § 2 KRO).

Istotne jest zastrzeżenie rządowe Polski zawarte w oświadczeniu ratyfikującym KPON [24] w związku z art. 12 § 1 KRO, na mocy którego Polska zastrzega sobie prawo do niestosowania postanowienia art. 23 ust. 1 lit. (a) Konwencji do czasu zmiany przepisów prawa polskiego. Do momentu wycofania zastrzeżenia pełnoletnia osoba niepełnosprawna (w przypadku dziewcząt wyjątkowo ukończenie 16 lat), której niepełnosprawność wynika z m.in. z niedorozwoju umysłowego, nie będzie mogła zawrzeć związku małżeńskiego, chyba że sąd na to zezwoli po spełnieniu warunków z art. 12 § 1 KRO (opisanych wcześniej).

W dziale II KRO uregulowano problematykę opieki nad ubezwłasnowolnionym całkowicie w art. 175-177. W doktrynie uznaje się, że opieka nie jest instytucją prawa rodzinnego, ponieważ stosunek prawny opieki nie wynika ani z małżeństwa, ani z pokrewieństwa. Należy ona do osobowego prawa cywilnego, jednak ze względu na funkcję i cel opieki 
uregulowano ją w KRO [25]. Zgodnie z art. 175 KRO do opieki nad ubezwłasnowolnionym całkowicie stosuje się odpowiednio przepisy o opiece nad małoletnim z zachowaniem przepisów poniższych. Opieka sprawowana jest bezpłatnie i zazwyczaj przez członków rodziny, co ją odróżnia od kurateli [25]. Zgodnie z przepisami, jeżeli wzgląd na dobro pozostającego pod opieką nie stoi temu na przeszkodzi, opiekunem ubezwłasnowolnionego całkowicie powinien być ustanowiony przede wszystkim jego małżonek, a w dalszej kolejności ojciec lub matka (art. 176 KRO). Opieka nad ubezwłasnowolnionym całkowicie ustaje z mocy prawa w razie uchylenia ubezwłasnowolnienia bądź zmiany ubezwłasnowolnienia całkowitego na częściowe (art. 177 KRO).

W dziale III KRO w art. 178 jest uregulowana instytucja kurateli, wobec której stosuje się ogólne przepisy o opiece oraz inne uregulowania. Kurator może być powołany w różnych celach (m.in. jako rodzaj wsparcia, tj. pomocy do prowadzenia różnych spraw albo spełnienia poszczególnej sprawy jako rodzaj nadzoru, np. dla nieletnich) i dla różnych osób (m.in. dla dziecka nienarodzonego, dla osoby ubezwłasnowolnionej częściowo, dla osoby niepełnosprawnej). Kuratela jest uchylana przez organ państwowy, gdy przestanie być uzasadniona (odpadnie jej cel) lub gdy zostanie ukończona sprawa, dla której była powołana (art.180 KR0). W doktrynie uznaje się, że ubezwłasnowolniony częściowo korzysta z większej samodzielności niż małoletni w wieku powyżej 13 lat, bowiem zgodnie z art. 181 KRO kurator dla niej jest powołany do zarządu majątkiem tylko w razie wyraźnego orzeczenia sądu w tej kwestii. Jednak biorąc pod uwagę „ograniczoną zdolność do czynności prawnych”, należy uznać kuratora za przedstawiciela ustawowego działającego w sferze stosunków majątkowych, z wyłączeniem czynności, które może dokonać sam ubezwłasnowolniony (np. zgoda na zabieg medyczny, zgodna na uznanie dziecka etc.) [25].

Natomiast na podstawie art. $183 \S 1$ i 2 KRO dla osoby niepełnosprawnej ustanawia się kuratora, jeżeli potrzebuje ona pomocy w zakresie prowadzenia swoich spraw, tj. wszelkich spraw bądź spraw określonego rodzaju albo nawet do załatwienia określonej sprawy. Zakres obowiązków i uprawnień kuratora określa sąd opiekuńczy. Kuratelę uchyla się na żądanie osoby niepełnosprawnej, dla której była ustanowiona. W wypadku osoby niepełnosprawnej nie mamy do czynienia z ubezwłasnowolnieniem, gdyż dotyczy to sprawy, gdy nie zostaje ono orzeczone zgodnie z art. $558 \mathrm{KPC}$.

Wszystkie powyższe instytucje opiekuńcze prawa cywilnego uregulowane w KRO w stosunku do dorosłych osób z NI, a więc na stałe ustanowiony opiekun albo kurator w związku z ubezwłasnowolnieniem osoby, są niezgodne z uregulowaniami międzynarodowymi. Jedynie instytucja kuratora dla osoby niepełnosprawnej, który jest powoływany do załatwiania określonych spraw, co nie wymaga ubezwłasnowolnienia, jest korzystna dla osoby z NI w stopniu umiarkowanym. Konwencja o prawach osób niepełnosprawnych wyklucza stałe formy pozbawienia zdolności do czynności prawnych i Polska powinna w tym zakresie dostosować prawo, stwarzając wsparcie asystentów prawnych i w ogóle zrezygnować z instytucji ubezwłasnowolnienia.

\section{Przepisy w zakresie postępowania cywilnego}

Dla każdej osoby, w tym osoby z NI w stopniu umiarkowanym, istotna jest możliwość korzystania z podmiotowości prawnej w kontekście dochodzenia jej praw przed sądami (postępowanie sądowe przed sądami powszechnymi i Sądem Najwyższym) albo innymi organami (postępowanie pozasądowe, np. przed mediatorem, komisją pojednawczą), a więc realna możliwość dochodzenia naruszonych praw. Zasady postępowania w sprawach cywilnych związanych z prawami majątkowymi (własność i inne prawa rzeczowe) i niemajątkowymi (z zakresu prawa rodzinnego i opiekuńczego, kurateli, prawa pracy, ubezpieczeń społecznych) stron stosunku cywilnego określa KPC [26]. W obrębie postępowania cywilnego można ponadto wyróżnić postępowanie procesowe i nieprocesowe. Zasadą jest, że sąd rozpoznaje sprawy w procesie (art.13 KPC), chyba że przepisy szczególne (z KPC czy innych ustaw) stanowią inaczej. Postępowanie nieprocesowe dotyczy spraw m.in. z zakresu prawa osobowego, prawa rodzinnego, opiekuńczego i kurateli [17].

Udział w postępowaniu cywilnym osoby z NI zależy od tego, czy jest ubezwłasnowolniona oraz czy sprawa bezpośrednio jej dotyczy. Każda osoba (fizyczna czy prawna) zgodnie z art. 64 § $1 \mathrm{KPC}$ posiada „zdolność sądową”, tj. zdolność występowania w procesie jako strona (tak jak posiada zdolność prawą), ale „zdolność procesową" (podejmowania czynności w sprawach cywilnych - składanie wniosków dowodowych etc.) zgodnie z art. 65 § 1 KPC mają osoby fizyczne z „pełną zdolnością do czynności prawnych" (osoby pełnoletnie i nieubezwłasnowolnione). Zarówno w doktrynie [26, 27, 28], jak i orzecznictwie [29] przyjęto, że „zdolność sądowa” to kategoria cywilnego prawa procesowego odpowiadająca kategorii cywilnego prawa materialnego - „zdolności prawnej”. Jej uzyskanie oraz utrata, w przypadku osób fizycznych, następuje tak jak „zdolności prawnej" - odpowiednio z chwilą urodzenia oraz śmierci człowieka.

Osoba fizyczna niemająca „zdolności procesowej” może podejmować czynności procesowe tylko przez swego przedstawiciela ustawowego (art. 66 KPC). Jednakże osoba fizyczna „ograniczona w zdolności do czynności prawnych” ma „zdolność procesową" w sprawach wynikających z czynności prawnych, których może dokonywać samodzielnie (art. 65 § 2 KPC). Również w tym przypadku nastąpiło odwołanie do norm prawa cywilnego materialnego - ograniczony zakres podejmowania czynności procesowych mają zatem małoletni, którzy ukończyli 13 lat, oraz osoby ubezwłasnowolnione częściowo (mające ograniczoną zdolność do czynności prawnych z art. $15 \mathrm{KC}$ ) i dotyczy on spraw wymienionych w KC, stanowiących o samodzielności małoletniego czy ubezwłasnowolnionego częściowo (art. 20, 21, 22 KC - przybliżone w części opracowania o KC) [28]. Przykładowo w sprawach dotyczących swojego zarobku małoletni posiada „pełną zdolność do czynności prawnych” i „pełną zdolność procesową” (może złożyć pozew czy ustalić pełnomocnika). Dodatkowe uprawnienia w zakresie „zdolności procesowej" małoletnim powyżej 13 lat i ubezwłasnowolnionym częściowo nadaje ustawodawca w art. 573 §1 KPC, osoba pozostająca pod władzą rodzicielską, opieką albo kuratelą 
ma bowiem zdolność do podejmowania czynności w postępowaniu dotyczącym jej osoby, chyba że nie ma „zdolności do czynności prawnych”. Poszerzenie „zdolności procesowej” następuje w tym wypadku tylko w sprawach dotyczących osoby, a nie jej majątku [28].

Ponadto w przepisach KPC podkreśla się podmiotowość człowieka bez względu na jego stan psychiczny lub wiek poprzez instytucję wysłuchania (w tym wysłuchania dziecka). Każdy człowiek w swojej sprawie powinien być przez sąd wysłuchany, np. obligatoryjne wysłuchanie osoby, której dotyczy wniosek o ubezwłasnowolnienie (art. 547 § 1 KPC).

W procesie cywilnym strony lub przedstawiciele ustawowi mogą działać osobiście lub przez pełnomocników (art. 86 $\S 1 \mathrm{KPC}$ ). Pełnomocnikiem może być adwokat lub radca prawny, ale również członkowie rodziny (małżonek, rodzeństwo, zstępni lub wstępni strony oraz osoby pozostające ze stroną w stosunku przysposobienia).

W ramach uzyskania dowodu z przesłuchania w postępowaniu procesowym zgodnie z art. 302 § 2 KPC w sprawach osób znajdujących się pod władzą rodzicielską, opieką lub kuratelą od uznania sądu zależy przesłuchanie bądź samej strony, bądź jej przedstawiciela ustawowego, bądź też obojga. Uzyskanie innych środków dowodowych jak krew (pobranie krwi w celu jej zbadania) może nastąpić tylko za zgodą osoby, której krew ma być pobrana, a jeżeli osoba ta nie ukończyła 13 lat lub jest ubezwłasnowolniona całkowicie - za zgodą jej przedstawiciela ustawowego (art. $306 \mathrm{KPC}$ ).

W trybie postępowania nieprocesowego uregulowane jest postępowanie w sprawach z zakresu prawa osobowego, do którego należą sprawy o ubezwłasnowolnienie z art. 544-560 KPC. Sprawy te jako dotykające najistotniejszych praw z grupy praw człowieka i poważnie ograniczające jego podmiotowość prawną rozpatruje sąd okręgowy (nie rejonowy) właściwy ze względu na miejsce zamieszkania lub pobytu osoby, której dotyczy wniosek o ubezwłasnowolnienie, w składzie aż trzech sędziów zawodowych (art. 544 § 1 i 2 KPC), zawsze w obecności prokuratora (art. $546 \S 2 \mathrm{KPC}$ ). Orzeczenie w przedmiocie ubezwłasnowolnienia może zapaść tylko po przeprowadzeniu rozprawy (art. $555 \mathrm{KPC}$ ). Do postępowania mogą wstąpić w każdym jego stadium organizacje pozarządowe (non-government organization - NGO), do których zadań statutowych należy ochrona praw osób niepełnosprawnych, udzielanie pomocy takim osobom lub ochrona praw człowieka (art. 546 § 3 KPC). Przedstawiciele NGO występują w sprawie w roli uczestnika w celu zapewnienia kontroli społecznej tego typu spraw [27]. Procedura ubezwłasnowolnienia zawiera możliwości czynnego uczestnictwa osoby, która ma być ubezwłasnowolniona, zawiera też wiele gwarancji zabezpieczających przed nadużywaniem tej instytucji, m.in. instytucję wstępnego wysłuchania osoby oraz wszechstronne zbieranie materiału dowodowego: wysłuchanie osoby, zeznania świadków, dokumentacja medyczna, opinie biegłych lekarzy specjalistów, obserwacja w zakładzie psychiatrycznym. Osoba jest chroniona poprzez możliwość ustanowienie doradcy tymczasowego dla ochrony jej interesów w trakcie trwania procesu, a także ma możliwości odwoławcze w zakresie ustanowionego ubezwłasnowolnienia z możliwością braków formalnych pisma (art. 560 § 1 KPC). Od postanowienia sądu przysługuje odwołanie do sądu II instancji, a następnie od postanowienia sądu II instancji, kończącego postępowanie w przedmiocie ubezwłasnowolnienia przysługuje skarga kasacyjna (art. $519^{1} \S 1$ KPC). Prawomocne postanowienie sądu jest skuteczne erga omnes od chwili uprawomocnienia się [27].

W przepisach KPC przewidziany jest specjalny kurator dla osoby niepełnosprawnej, którego sąd opiekuńczy ustanawia na wniosek tej osoby bądź za jej zgodą na wniosek NGO (do których zadań statutowych należy ochrona praw osób niepełnosprawnych). Sąd może ustanowić kuratora z urzędu wówczas, gdy stan osoby niepełnosprawnej wyłącza świadome wyrażenia zgody bądź możliwość złożenia wniosku, a także w razie oddalenia wniosku o ubezwłasnowolnienie z art. 558 § 2 KPC (art. 600 § $1 \mathrm{KPC}$ ).

Regulacje KPC biorą pod uwagę również faktyczną niezdolność osoby do spostrzegania lub komunikowania swych spostrzeżeń, np. sąd na podstawie stwierdzenia „niezdolności faktycznej" (wydanej na podstawie opinii biegłego psychiatry lub psychologa) nie dopuści osoby do zeznań w charakterze świadka (art. 259 KPC). W procedurze administracyjnej istnieją analogiczne przepisy. Zatem prawo polskie bierze pod uwagę faktyczną zdolność osoby do składania zeznań, co jest przepisem ochronnym wobec osób z NI, w tym w stopniu umiarkowanym, w przypadku gdyby jej zeznania mogłyby być dla niej niekorzystne.

Zaprezentowane przepisy KPC, regulujące wszystkie kwestie związane z reprezentacją przed sądem osób nieposiadających „zdolności procesowej”, są zgodne z regulacjami międzynarodowymi (KPON) i Konstytucją. Prawidłowe są przepisy o „faktycznej niezdolności” strony postępowania nakazujące nie uwzględniać zeznań osób niezdolnych do spostrzegania lub komunikowania swych spostrzeżeń. Regulacje związane z ubezwłasnowolnieniem (też z ustanowieniem opieki) są krytykowane, jednak nie ze względu na braki procesowe, ale sam fakty istnienia tej instytucji w prawie materialnym, co zostało zaprezentowane w części o przepisach z KC oraz KRO. Również przepisy związane z wydawaniem specjalnych zezwoleń na zawarcie małżeństwa przez osoby z NI, w tym w stopniu umiarkowanym, nie są zgodne z prawem międzynarodowym (KPON).

\section{DYSKUSJA}

W pracy stosowano termin „niepełnosprawność intelektualna" (intellectual disability), którego użycie jest w literaturze ciągle dyskutowane w kontekście używanego równolegle terminu „upośledzenie umysłowe” (mental retardation). Większość autorów uważa jednak że najbardziej adekwatne jest używanie tego pierwszego terminu w celu uniknięcia stygmatyzacji i marginalizacji [30], a więc należytego poszanowania osoby z NI jako podmiotu prawa. Termin NI jest pozytywnie przyjmowany i używany zarówno przez środowiska naukowe, w tym międzynarodowe, jak i działające na rzecz 
osób niepełnosprawnych [21,31,32]. Termin NI jest również wprowadzony w miejsce „upośledzenia umysłowego” w klasyfikacji diagnostycznej amerykańskich psychiatrów - DSM-V, obowiązującej od 2013 r. Natomiast w polskim prawie nadal używane jest anachroniczny termin „niedorozwój umysłowy” w podstawowych aktach prawa cywilnego przytoczonych w pracy (KC, KRO, KPC).

Pozbawianie osoby pełnoletniej „zdolności do czynności prawnych" w formie ubezwłasnowolnienia jest instytucją, od której odchodzi się w regulacjach prawa międzynarodowego. W doktrynie [22] i orzecznictwie [33] jasno określony jest cel ustanowienia ubezwłasnowolnienia osoby - jest nim wyłącznie dobro osoby chorej, a nie dobro rodziny czy innej osoby. Zasadniczo ma na celu zabezpieczenie jej przed skutkami jej własnych, niekorzystnych dla niej decyzji. Decyzje te zatem podejmuje, po ustanowieniu ubezwłasnowolnienia, przedstawiciel ustawowy. Jednocześnie liczni autorzy [20, 21] podkreślają nieadekwatność środka, jakim jest ubezwłasnowolnienie, w stosunku do rzeczywistej ochrony i zabezpieczenia praw osoby z NI. Skutkiem ubezwłasnowolnienia jest bowiem brak „zdolności do czynności prawnych”, co oznacza, że osoba taka nie może: spisać testamentu (brak prawa do dziedziczenia), głosować i kandydować w wyborach (brak praw wyborczych), legalnie pracować (brak prawa do pracy), samodzielnie się zameldować czy być krwiodawcą. Jest to przykładowa lista, gdyż w gruncie rzeczy osoba taka traktowana jest przez prawo jak dziecko pod opieką. Zimna-Parjaszewska podnosi, że cały system związany z ubezwłasnowolnieniem jest wadliwy i nie sprzyja ochronie praw [20]. Inni autorzy wskazują na nadużycia w stosowaniu ubezwłasnowolnienia całkowitego w Polsce (np. stosowanie go bez względu na orzeczony stopień NI) oraz brak ubezwłasnowolnienia w ustawodawstwach innych krajów, które ratyfikowały KPON [21]. Szeroczyńska [12] dowodzi, że wiele państw, które ratyfikowały KPON, nie posiada instytucji, która by w sposób trwały pozbawiała osobę „zdolności do czynności prawnych” ze względu na zapis art. 12 KPON, w którym proklamowana jest zasada „równości wobec prawa” i korzystania w pełni ze swojej podmiotowości prawnej. Zastrzeżenia rządu polskiego w tym zakresie dopuszczające w prawie polskim instytucję ubezwłasnowolniania oraz zawieranie małżeństw osób z NI (niedorozwiniętych umysłowo) tylko za zgodą sądu [24] są w literaturze szeroko krytykowane, ze względu na łamanie zasad z KPON (m.in. zasady autonomii, zasady równości wobec prawa, prawa do założenia rodziny). Polskie tłumaczenie angielskiego terminu legal capacity z art. 12 KPON na „zdolność prawną” pozwoliło na błędną interpretację postanowień KPON. Termin legal capacity rzeczywiście literalnie oznacza „zdolność prawną”, jednak w prawie międzynarodowym znaczenie tego terminu jest szersze niż w prawie polskim, gdyż oznacza nie tylko zdolność do bycia podmiotem prawa (polskie rozumienie terminu „zdolność prawna”), ale również możliwość działania na równi z innymi osobami (polskie rozumienie terminu „zdolności do czynności prawnych”) [34]. Zatem termin legal capacity z KPON w prawie polskim jest raczej odpowiednikiem podmiotowości prawnej, na którą składa się „Zdolność prawna” oraz „zdolność do czynności prawnych” [15].
Jednocześnie KPON (art. 12 ust. 3) zobowiązuje państwa-strony do udzielania pomocy w korzystaniu z tej zdolności, dla osób które tego potrzebują, co jest promowaniem modelu „wspomaganego podejmowania decyzji", przy udziale asystenta prawnego. Postuluje się, aby instytucja asystenta nie była jedynie elementem prawa socjalnego, ale przede wszystkim prawa cywilnego, wprowadzona zamiast regulacji o opiekunie osoby ubezwłasnowolnionej. Natomiast „zdolność do czynności prawnych" winna być połączona ze stanem faktycznym, a nie prawnym [35]. Nie jest to propozycja nowa. Do krajów nieposiadających trwałego ubezwłasnowolnienia osoby, ale zastępstwo w wykonaniu określonych czynności, należą m.in.: Niemcy (decyzję osoby „faktycznie niezdolnej do czynności prawnych” można unieważnić przed sądem), Wielka Brytania (osoba może posiadać „brak kompetencji” w odniesieniu do danej czynności czy decyzji) lub Kanada (w wyjątkowym przypadku można powołać substytuta). W roli asystenta wspomagającego, który ma wyznaczony przez sąd zakres kompetencji, występują osoby różnie nazywane - w Niemczech jest to przedstawiciel (berteung), w Szwecji - powiernik, w Wielkiej Brytanii - agent [12]. Postuluje się zatem rezygnację z instytucji ubezwłasnowolnienia jako anachronicznego modelu zastępczego podejmowania decyzji na rzecz propagowanego w KPON modelu opartego o wspierane podejmowanie decyzji [35, 36, 37], co jest rekomendowane również przez urząd Rzecznika Praw Obywatelskich [38]. Zdaniem Kijaka w Polsce szczególnie wobec ubezwłasnowolnionych osób z NI znikoma jest realizacja „idei życia wspieranego” (supported living) [39], gdzie niepełnosprawny mógłby decydować o swoim życiu, korzystając w tym z pomocy innych w niezbędnym zakresie. Osoba ubezwłasnowolniona całkowicie zgodnie z art. 11 § 1 KRO nie może zawrzeć małżeństwa, co również jest niezgodne z postanowieniami KPON. Tak samo nieprawidłowy jest przepis $\mathrm{z}$ art. 12 § 1 KRO mówiący o tym, że nie może zawrzeć małżeństwa osoba dotknięta „niedorozwojem umysłowym”. Oprócz stygmatyzującego charakteru użytych określeń należy uznać niezgodność tych przepisów z art.12 KPON, bowiem cecha niepełnosprawności intelektualnej staje się podstawą odmowy zawarcia małżeństwa, co w literaturze uznawane jest za klasyczną dyskryminację [40, 41]. Dyskryminacja jest bowiem gorszym traktowaniem ze względu na pewną cechę (w tym wypadku niedorozwój umysłowy). Tymczasem KPON gwarantuje osobom niepełnosprawnym prawo do zawarcia małżeństwa jako realizację prawa do życia rodzinnego (art. 23 ust. 1), uznając jednocześnie, że osoba może być niezdolna do zawarcia małżeństwa. W prawie polskim mamy nieprawidłową, odwrotną konstrukcję. Zgodnie z KRO osoby z NI nie mają prawa (zdolności) do zawarcia małżeństwa (jako niedorozwinięte), a wyjątkowo sąd może im na małżeństwo zezwolić [41]. Zamiast wadliwych przepisów KRO Rzecznik Praw Obywatelskich proponuje użycie definicji opisowej co do przeszkód w zakresie zawierania małżeństw: „(...) nie będzie mogła zawrzeć małżeństwa osoba dotknięta zaburzeniami psychicznymi, które nie pozwalają tej osobie kierować swoim postępowaniem oraz uświadomić sobie znaczenia i konsekwencji obowiązków wynikających z zawarcia małżeństwa" [38]. 


\section{WNIOSKI}

Naruszeniem prawa międzynarodowego jest pozostawienie w prawie polskim instytucji ubezwłasnowolnienia oraz opieki, a także ograniczenia w zawarciu małżeństwa ze względu na „niedorozwój umysłowy”. Zaleca się usunięcie instytucji ubezwłasnowolnienia oraz opieki z prawa polskiego, wyrażających „zastępczy system podejmowania decyzji”, a w ich miejsce wprowadzenie osobowych form „wspieranego podejmowania decyzji" w postaci pomocy asystenta prawnego i innych osób.

Zgodnie z prawem międzynarodowym (art. 12 ust. 3 KPON) Polska jest zobowiązana udzielić pomocy w podejmowaniu decyzji osobom z NI, w tym w stopniu umiarkowanym, więc wymagane jest, by w przepisach osobowego prawa cywilnego (KRO), w miejsce instytucji opiekuna, wprowadzić asystenta prawnego. Zakres pomocy świadczonej przez asystenta powinien być indywidualnie oznaczony w postaci określenia „faktycznej niezdolność do czynności” osoby NI (w zakresie której ma prawo działać asystent) w postanowieniu sądu, aby zapewnić jak największą autonomię i niezależność osobie z NI.

Przepisy polskie związane z zakazem zawarcia małżeństwa przez osoby z NI, w tym w stopniu umiarkowanym, nie są zgodne z prawem międzynarodowym (KPON). Zaleca się likwidację zakazu zawierania małżeństw przez osoby z NI z prawa polskiego oraz wprowadzenia definicji opisowej, co do przeszkód w zakresie zawarcia małżeństwa, uwzględniającej brak świadomości osoby.

Używanie stygmatyzującego terminu „niedorozwój umysłowy" w aktach prawa cywilnego nie sprzyja ochronie podmiotowości prawnej osób z NI, w tym w stopniu umiarkowanym, oraz jest niezgodny z prawem międzynarodowym. Postuluje się wprowadzenie terminu „niepełnosprawność intelektualna” we wszystkich aktach prawnych w Polsce.

\section{PIŚMIENNICTWO}

1. Powszechna deklaracja praw człowieka z 10 grudnia 1948 r. Rezolucja Zgromadzenia Ogólnego Narodów Zjednoczonych nr 217/III z 10.12.1948 r.

2. Międzynarodowy pakt praw obywatelskich i politycznych z 16 grudnia 1966 r. Dz.U. z 1977 r., nr 38, poz. 167

3. Międzynarodowy pakt praw gospodarczych, społecznych i kulturalnych z 16 grudnia 1966 r. Dz.U. z 1977 r., nr 38, poz. 169.

4. Europejska konwencja o ochronie praw człowieka i podstawowych wolności sporządzona przez Radę Europy w Rzymie dnia 4 listopada $1950 \mathrm{r}$ (ratyfikowana przez Polskę w 1993 r.) Dz.U. z 1993 r., nr 61, poz. 284.

5. Deklaracja praw osób z upośledzeniem umysłowym z 20 grudnia 1971 r. Uchwała Zgromadzenia Ogólnego Narodów Zjednoczonych nr 2856 (XXVI) z 20.12.1971 r.

6. Deklaracja praw osób niepełnosprawnych z dnia 9 grudnia 1975 r. Rezolucja Zgromadzenia Ogólnego Narodów Zjednoczonych nr 3447(XXX) z 09.12.1975 r

7. Standardowe zasady wyrównywania szans osób niepełnosprawnych z 20 grudnia 1993 r. Rezolucja Zgromadzenia Ogólnego Narodów Zjednoczonych nr 48/96 z 20.12.1993 r.

8. Konwencja o prawach osób niepełnosprawnych z 13 grudnia 2006 r. Rezolucja Zgromadzenia Ogólnego Narodów Zjednoczonych nr 61/106, ratyfikowana przez Polskę w 2012 r. Dz.U. z 2012 r., poz. 1169.

9. Rekomendacja w sprawie zasad dotyczących prawnej ochrony niekompetentnych osób dorosłych z dnia 23 lutego 1999 r. Rekomendacja Komitetu Ministrów Rady Europy nr R (99) 4 z 23.02.1999 r.
10. Rekomendacja w sprawie planu działania Rady Europy na lata 20062015 z dnia 5 kwietnia 2006 r. Rekomendacji Komitetu Ministrów Rady Europy nr Rec (2006) 5.

11. Rezolucja „Dostęp do praw osób niepełnosprawnych oraz ich pełna i aktywna partycypacja w życiu społecznym” z 26 stycznia 2009 r. Rezolucja Zgromadzenia Parlamentarnego Rady Europy nr 1642 (2009) z 26.01.2009 r.

12. Szeroczyńska M. Ubezwłasnowolnienie i alternatywne formy pomocy w realizowaniu zdolności do czynności prawnych osób z niepełnosprawnością intelektualną w regulacjach międzynarodowych oraz w prawie obcym, na przykładzie Estonii, Niemiec, Szwecji, Wielkiej Brytanii i Kanady (stanu Manitoba). In: Kędziora K, editor. Jeśli nie ubezwłasnowolnienie, to co? Prawne formy wsparcia osób z niepełnosprawnością intelektualną. Warszawa: Polskie Towarzystwo Prawa Antydyskryminacyjnego; 2012. p. 15-63.

13. Konstytucja RP z dnia 2 kwietnia 1997 r. Dz.U. z 1997 r., nr 78, poz. 483.

14. Ustawa z dnia 23 kwietnia 1964 r. - Kodeks cywilny. Dz.U. z 1964 r., nr 16, poz. 93 ze zm.

15. Ustawa z dnia 25 lutego 1964 r. - Kodeks rodzinny i opiekuńczy. Dz.U. z 2015 r., nr 0, poz. 583 ze zm.

16. Ustawa z dnia 17 listopada 1964 r. - Kodeks postępowania cywilnego. Dz.U. z 1964 r., nr 43, poz. 296 ze zm.

17. Flaga-Gieruszyńska K. Postępowanie cywilne. Pytania. Warszawa: C.H. Beck; 2015. p. 4.

18. Baza Aktów Prawnych Unii Europejskiej - wersja polska. http://eur-lex. europa.eu/homepage.html?locale=pl (14.01.2016).

19. Internetowy System Aktów Prawnych. http://isap.sejm.gov.pl/ (14.01.2016).

20. Zima-Parjaszewska M. Ubezwłasnowolnienie w świetle Konstytucji RP oraz Konwencji o Prawach Osób z Niepełnosprawnościami. Ekspertyza prawna dotycząca ubezwłasnowolnienia. Warszawa: Polskie Towarzystwo Prawa Antydyskryminacyjnego. http://www.ptpa.org.pl/site/assets/ files/1029/ekspertyza_osi_-_ubezwlasnowolnienie.doc (14.01.2016).

21. Kędziora K, editor. Jeśli nie ubezwłasnowolnienie, to co? Prawne formy wsparcia osób z niepełnosprawnością intelektualną. Warszawa: Polskie Towarzystwo Prawa Antydyskryminacyjnego; 2012. http://www.soswzgierz.pl/web/uploads/files/JESLI\%20NIE\%20UBEZWLASNOWOLNIENIE\%20T0\%20CO\%20-\%20PUBLIKACJA.pdf (14.01.2016).

22. Ciszewski J, editor. Kodeks cywilny. Komentarz. Warszawa: LexisNexis; 2014. p. 38-63.

23. Grzeszczak R, Szeroczyńska M. Ubezwłasnowolnienie i inne formy wsparcia dla osób z niepełnosprawnością intelektualną w Polsce - teoria i praktyka. In: Kędziora K, editor. Jeśli nie ubezwłasnowolnienie, to co? Prawne formy wsparcia osób z niepełnosprawnością intelektualną. Warszawa: Polskie Towarzystwo Prawa Antydyskryminacyjnego; 2012. p. 15-63.

24. Oświadczenie Rządowe z dnia 25 września 2012 r. w sprawie mocy obowiązującej Konwencji o prawach osób niepełnosprawnych, sporządzonej w Nowym Jorku dnia 13 grudnia 2006 r. Dz.U. z 2012 r. nr 0, poz.1170.

25. Smyczyński T. Prawo rodzinne i opiekuńcze. Warszawa: C.H. Beck; 2005. p. 281-307.

26. Flaga-Gieruszyńska K, editor. Postępowanie cywilne. Komentarz praktyczny dla sędziów i pełnomocników procesowych. Warszawa: C.H. Beck; 2014. p. 65-70.

27. Góra-Błaszczykowska A, editor. Kodeks postępowania cywilnego. Tom I. Komentarz art. 1-729. Warszawa: C.H. Beck; 2016. p. 274-1707.

28. Zieliński A, Flaga-Gieruszyńska K. Kodeks postępowania cywilnego. Warszawa: C.H. Beck; 2014.p. 149-1113.

29. Wyrok SN z 17 lipca 1997 r. III CKN 149/97, OSP 2000, nr 4, p. 63.

30. Bobińska K, Gałecki P. Rys historyczny, terminologia, definicja, nozologia, kryteria rozpoznawania niepełnosprawności intelektualnej. In: Bobińska K, Petras T, Gałecki P, editor. Niepełnosprawność intelektualna - etiopatogeneza, epidemiologia, diagnoza, terapia. Continuo: Wrocław; 2012. p. 27-8.

31. Wehmeyer ML. Disability, disorder, and identity. Intellectual and Developmental Disabilities 2013;51(2):122-6.

32. Tassé MJ. What's in a name? Intellectual and Developmental Disabilities 2013;51(2):113-6.

33. Postanowienie SN z 29 grudnia 1983 r. I CR 377/83, Lexis.pl 321096.

34. McSherry BM. Legal capacity under the Convention on the Rights of Persons with Disabilities. J Law Med 2012;20:22-7. https://ssrn.com/ abstract $=2490972$ (14.01.2016).

35. Dinerstein RD. Implementing legal capacity under Article 12 of the UN Convention on the Rights of Persons with Disabilities: the difficult road from guardianship to supported decision-making. Hum Rts Brief 2011;19:8. 
36. Kleniewski I, Szeroczyńska M. Założenia uregulowania w polskim prawie insty tucji asystenta prawnego osoby z niepełnosprawnością intelektualną lub psychospołeczną. In: Kędziora K, editor. Jeśli nie ubezwłasnowolnienie, to co? Prawne formy wsparcia osób z niepełnosprawnością intelektualną. Warszawa: Polskie Towarzyst wo Prawa Antydyskryminacyjnego; 2012. p. 15-63.

37. Zima-Parjaszewska M. Równość osób z niepełnosprawnościami wobec prawa - sytuacja osób ubezwłasnowolnionych. In: Najważniejsze wyzwania po ratyfikacji przez Polskę Konwencji ONZ o Prawach osób Niepełnosprawnych. Biuletyn Rzecznika Praw Obywatelskich Źródła 2012;10:16-25.

38. Trociuk S. O potrzebie zmian w polskim systemie prawnym w związku z procedurą ratyfikacji Konwencji o prawach osób niepełnosprawnych. In: Niepełnosprawność - nowe spojrzenie. Materiały z Międzynarodowej
Konferencji nt. „Węzłowe Zagadnienia wdrażania Konwencji Narodów Zjednoczonych o prawach osób niepełnosprawnych oraz Europejskiej strategii w sprawie niepełnosprawności 2010-2020". Warszawa; 2012. p.13-7.

39. Kijak RM. Niepełnosprawność intelektualna. Między diagnozą a działaniem. Warszawa: Instytut Rozwoju Służb Społecznych; 2013.

40. Pawlak P. Prawo osób niepełnosprawnych do życia rodzinnego - analiza zmian społeczno-prawnych. In: Stępkowska KM, Stępkowska JK, editors. Instytucja rodziny wczoraj i dziś. Perspektywa interdyscyplinarna. Tom 1. Między prawem i rynkiem. Lublin: Politechnika Lubelska; 2012. p. 52-8.

41. Zima M. Przesłanki zawarcia małżeństwa przez osoby niepełnosprawne. In: Walaszkiewicz AM, editor. Polska droga do Konwencji o prawach osób niepełnosprawnych ONZ. Kraków: PFRON; 2008. p. 117. 